Fall 2010

\title{
History, Memory, and Historic Districts in Chicago
}

Theodore J. Karamanski

Loyola University Chicago, tkarama@luc.edu

Follow this and additional works at: https://ecommons.luc.edu/history_facpubs

Part of the History Commons

\section{Recommended Citation}

Karamanski, Theodore J. 2010. "History, Memory, and Historic Districts in Chicago". The Public Historian. 32 (4): 33-41.

This Article is brought to you for free and open access by the Faculty Publications and Other Works by Department at Loyola eCommons. It has been accepted for inclusion in History: Faculty Publications and Other Works by an authorized administrator of Loyola eCommons. For more information, please contact ecommons@luc.edu. c) (i) $\Theta \Theta$

This work is licensed under a Creative Commons Attribution-Noncommercial-No Derivative Works 3.0 License. (c) University of California Press, 2010. 


\title{
History, Memory, and Historic Districts in Chicago
}

\author{
THEODORE J. KARAMANSKI
}

\begin{abstract}
Across America, National Register Historic Districts have done a better job helping to preserve building stock and stabilize communities than they have of meeting the articulated goal of With a Heritage So Rich, the foundational 1966 study that gave birth to the National Register of Historic Places. According to that report, historic sites were to "give a sense of orientation to our society" and help to implant in people "values of time and place." This article looks at the evolution of historic districts in Chicago, Illinois through the lens of public memory. It explores the relationship between "official" memory and gentrification, "vernacular memory" and community preservation through the story of two waves of National Register District creation in Chicago, first in the 1980s led by real estate developers and a second in the late 1990s.
\end{abstract}

Key words: Historic districts, Chicago, memory, neighborhoods, gentrification

HISTORIC DISTRICTS perhaps more than any other aspect of the National Historic Preservation Act fulfill the planning function that was envisioned by American mayors when they lobbied for a national historic preservation system. Districts are a tool that allows communities to conserve housing stock, preserve the local character of neighborhoods, and, not least of all, stabilize and even enhance property values. What is too often lost sight of, however, is the over-arching goal of historic preservation as expressed in the foundational 1966 study, With a Heritage So Rich. That report articulated the aspiration that preservation "give a sense of orientation to our society, using structures

The Public Historian, Vol. 32, No. 4, pp. 33-41 (November 2010). ISSN: 0272-3433, electronic ISSN 1533-8576.

(C) 2010 by The Regents of the University of California and the

National Council on Public History. All rights reserved.

Please direct all requests for permission to photocopy or reproduce article content through the

University of California Press's Rights and Permissions Web site: www.ucpressjournals.com/reprintInfo.asp. DOI: 10/1525/tph.2010.32.4.33.

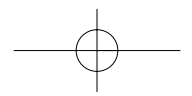


and objects of the past to establish values of time and place."1 Yet after a generation of preservation activity and the creation of literally thousands of historic districts in the United States, it is much easier to appreciate the impact of districts on taxation and real estate evaluation than on public memory and civic identity.

A look at the evolution of historic districts in Chicago illustrates the problems and prospects related to using historic districts to "establish values of time and place." The city's first historic districts, as was typically the case in many other cities, were elite residential districts such as the Prairie Avenue Historic District. It was a fashionable neighborhood that had boasted mansions designed by the likes of Henry Hobson Richardson, Solon Beman, and Daniel Burnham, but by the 1970s Prairie Avenue had fallen on hard times. Historic district designation at that time succeeded in contributing to the preservation of the best of what remained and paving the way for the neighborhood's revival as a prestigious address. Not only were architectural works of art saved, but due to a series of sidewalk exhibit panels erected by the Commission on Chicago Landmarks and regular tours offered by the Glessner House Museum, the story of the people and era that made the district historically significant was regularly presented to the public.

To some extent the creation of Prairie Avenue was an exercise in what historian John Bodnar has called "official memory," stories constructed and conveyed under government sponsorship in order to encourage social cohesion. ${ }^{2}$ Of course, at the time, the City of Chicago had to be persuaded and cajoled into cooperation by architects and history buffs who valued Prairie Avenue's remains. Their task was made easier because the district told a story that had obvious significance to local history and architecture with Gilded Age luminaries like George Pullman and Marshall Field, and their stunning mansions. The district preserved a built environment that held a prominent place in the city's public memory, a physical tie to historical images of the Columbian Exposition's White City and the time when Chicago was truly the "city with big shoulders." Prairie Avenue's early identification, preservation, and interpretation are reflected in elite historic districts across the country, such as Rittenhouse Square or Society Hill in Philadelphia or Nob Hill in San Francisco. Physically exquisite spaces and stories about the lives of the rich and famous are and will remain a core part of the common consensual memory of urban America.

While elite districts of high-style buildings played an important role in establishing the historic district concept, there were trends afoot in the 1970s that would change the trajectory of historic districts. Inspired by social his-

1. United States Conference of Mayors, With a Heritage So Rich, quoted in Robin Elisabeth Datel, "Preservation and a Sense of Orientation for American Cities," Geographical Review 75, no. 2. (April 1985): 125-41.

2. John Bodnar, Remaking America: Public Memory, Commemoration, and Patriotism in the Twentieth Century (New York: Princeton University Press, 1993).

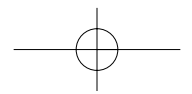


torians' call for "history from the bottom up," the definition of what was potentially "historically significant" was greatly broadened. Preservation felt this fresh breeze when the National Park Service advocated that the states begin to "democratize" the National Register. The goal was to ensure that the breadth and diversity of the American experience was reflected in what is preserved. Hard on the heels of this change came the famed "literary turn," with its mantra that the past has always been a story constructed by purposeful tellers. Thus just as preservationists were confronted with a wide variety of new and vernacular objects, sites, and districts, the academy basically said any attempt to determine significance was essentially relative. The historian's job was downgraded from the naïve task of determining what was true in the past, to constructing narratives about the past. At the time I was working with an architectural firm doing historic preservation consulting, and a joke among the staff was, "any historian worth paying could make a credible argument that anything was eligible for the National Register."

Meanwhile in urban America, developers caught on to the potential of historic districts to stimulate real estate values. Chicago presents a good example of savvy developers who consciously pushed the boundaries of historic district definition as part of an overt program of gentrification. "I'd like to do a neighborhood every quarter," one developer said. ${ }^{3}$ While this effort affected low-income residents negatively, the process provided public historians with an opportunity to be more pro-active in protecting vernacular cultural resources. By the beginning of the twenty-first century, vast sections of the City of Chicago had been designated as historic districts.

What has been the gain for public memory in this historic preservation process? Has the multiplication of districts diluted urban historical consciousness or has it been democratized? Two historic district initiatives in Chicago, separated by twenty years, help to provide an answer to those questions.

The Sheridan Park Historic District was created amid great controversy in 1985 at a time when the neighborhood was on the verge of gentrification. The district is located in the community known as Uptown. The area boomed in the 1920s, when theaters, dance halls, night clubs, even movie studios thrived and gracious apartment buildings were constructed. The young urban professionals of that era flocked to the neighborhood and walked down the streets with the likes of Charlie Chaplin, Gloria Swanson, and Wallace Beery. After World War II the neighborhood declined; large apartments were subdivided and the community became a gateway for rural whites and Native Americans lured to the city by the prospect of manufacturing jobs. When those jobs began to rust away, the Uptown area slid into slum status, and arson-for-profit became the community's most lucrative business. Also emerging in the early 1980s were the vague outlines of another trend: a handful of newcomers were attracted to Uptown because of its vintage housing stock and proximity to Lake

3. David Burnham, "Making History," The Reader 15, no. 43 (July 25, 1986): 18.

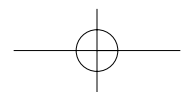


Michigan. For these young urban pioneers, historic preservation legislation appeared to be a tool for reinventing Uptown. The trouble was that while Uptown had an aging housing stock, its structures had none of the fancy pedigree of Prairie Avenue architecture. It would take creative thinking and social history to craft an argument that could meet National Register of Historic Places criteria.

A young historian, Daniel Bluestone, had the necessary creativity. A couple of years earlier he had failed in an attempt to nominate an apartment building in Uptown. The client who hired him to secure the designation and its attendant tax credit later admitted, "I was ready to kill him." Bluestone was able to salvage the relationship and secure another contract, however, by noting that if the nondescript apartment building were part of a historic district it could still secure designation. At the time Bluestone was a newly minted history Ph.D. with an interest in the development of vernacular urban forms like the small apartment buildings that once thrived in Uptown. Bluestone, who went on to head the Historic Preservation Program in the University of Virginia's School of Architecture, carved out of Uptown a district of gracious single-family homes and vintage apartment buildings. He called the area "Buena Park," a name briefly used to designate a train station when the area was a suburb of Chicago. The Buena Park district did have a number of buildings designed by notable architects such as George Maher of the Prairie School, but Bluestone went on to argue that much of the area's significance derived from its variety of brick apartment buildings that reflected "a transition in urban residential pattern." His nomination argued that behind the façade of what appeared to be ordinary apartments was an important story in architectural and social history. Buena Park was listed on the National Register in $1984 .^{4}$

Bluestone's successful nomination was important because it pointed the way for other developers to use historic districts to create gentrification zones within the Uptown community. Detailed research and a determined developer could reinvent Uptown one bite at a time. Randall Lange, a savvy real estate investor, immediately grasped this and set his sights on a much more prosaic part of Uptown, soon to be renamed "Sheridan Park." Historical research by a University of Illinois-Chicago professor and neighborhood property owner, Martin Tangora, documented the architects who designed the numerous apartment buildings in the area. Tangora shrewdly characterized them as second-tier designers whose work as a body was not unique, but typical of a time and place, and therefore it reflected the "broad pattern of American history."5 Like Buena Park before it, Sheridan Park took its name from a late nineteenth-century railroad station. ${ }^{6}$

4. Daniel Bluestone, Buena Park Historic District, National Register for Historic Places Nomination Form, 1984, p.17, http://gis.hpa.state.il.us/hargis/PDFs/201279.pdf.

5. Larry Bennett, Neighborhood and Politics: Chicago and Sheffield (New York: Garland, 1997), 220-24.

6. Martin Tangora, Sheridan Park Historic District, National Register for Historic Places Form, 1985, Section 8, p. 3.

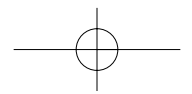


People who had lived there for fifty years never knew the area as "Sheridan Park." To them it was "Heart of Uptown” or simply Uptown. The new name of the community was a critical step in its reinvention as a real estate development. To well-off Chicagoans the name Uptown epitomized burnt-out buildings, street corner bums swigging cheap wine from brown paper bags, and public aid recipients. Bluestone, Tangora, and Lange's renaming of the community was an overt attempt to appropriate the past in service of a new future. Pushed aside were contemporary notions of Uptown as “Chicago's most diverse community," a mix of southern whites, American Indians, Hispanics, and Asians. The historic district nominations were a clear contest over the past waged in the newspapers, the city council, and in six-flat buildings where owners terminated the leases of their tenants. The most relevant place where this contest was waged, however, was the Illinois Historic Sites Advisory Council, where National Register nominations were reviewed. The structure of this body, made up of historians, architects, archeologists, and preservation activists, as well as the legal guidelines of the National Register of Historic Places, privileged the footnoted academic arguments of Dr. Tangora over the recollections and social concerns of people who lived and worked in the community for years. The Council eventually approved the nomination unanimously. It was a classic case of a contested past arising from a contested vision of the future. Nobody argued that the term "Sheridan Park" had not been used briefly in the past; what was at stake was the relevance of that fact. Tangora's ability to utilize the forms of the historic preservation system ensured that his interpretation of the neighborhood's past and the developer's label for its future would prevail.

Immediately after designation, renovated apartment buildings began to advertise themselves as being in "historic Sheridan Park" or as a "cornerstone of the Sheridan Park historic district." Randall Lange invested heavily in his newly named community, and by the end of the decade he controlled units containing more than five hundred apartments. It proved a lucrative investment. Within two years of designation, the medium price of a condominium unit increased from $\$ 49,000$ to $\$ 67,000$. Good, creative history clearly paid dividends. ${ }^{7}$

Sheridan Park also was a key benchmark in the development of historic districts in Illinois. The acceptance of Sheridan Park's plainly vernacular, unexceptional character as meeting National Register criteria opened up the floodgates for a stream of new, equally architecturally prosaic districts being accepted on the grounds that they documented the evolution of public space in the city. Some of these districts were promoted for the same commercial reasons that gave birth to Sheridan Park; others were the result of community initiatives where local pride, a desire to protect old buildings, and the State of Illinois's five-year property tax freeze for National Register structures inspired district nominations. Within twenty years there would be thirty-two

7. Bennett, Neighborhood and Politics, 223.

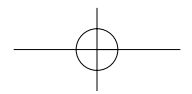


National Register Districts and fifty Chicago Landmark Districts in the city. Chicago was close to achieving the goal articulated in the middle of the Sheridan Park fight by Philip Krone, an attorney-developer-political insider, that all of Chicago should be a historic district. What would be gained and what would be lost if the entire city was a historic district? On the surface this would seem to be the achievement of a democratized history, perhaps at the risk of trivializing historic district status. It would certainly be a democratization of the preservation tax credits, which might be a good thing. ${ }^{8}$

A history rooted in the life and memory of a community, however, cannot be had simply by crafting a narrative that meets State Office of Historic Preservation and National Park Service standards. Public history professionals have the skill and perhaps even the responsibility to work with developers interested in a strictly commercial preservation goal. Preserving the historic fabric of a city, regardless of the motive, protects a material culture link to the past and keeps open a potential avenue of dialogue. Yet a community of public memory will not emerge from most commercial preservation projects because there is no social investment in the historical narrative laid out in the district nomination. A history that is built upon the vernacular memory of the people who live in a historic district, a history that is both felt and understood, lived as well as footnoted, is a history that can fulfill historic preservation's foundational goal to use "structures and objects of the past" to "give a sense of orientation to our society."

Fifteen years after the Sheridan Park designation, the City of Chicago took a big step toward including a large portion of the city within a historic district. In 2000, Mayor Richard M. Daley started a program to promote the appreciation of the more than 100,000 bungalows in Chicago. The Chicago bungalow, distinctly more modest than its California cousin, is a one-and-a-halfstory brick home. Huge numbers of these were built during the prosperous years between 1915 and 1930, and they make up about one third of the city's housing stock. Ironically, an older Daniel Bluestone, respected for his knowledge of Chicago's built environment, played a role in developing the historical argument for bungalow preservation. Since 2000, six neighborhood bungalow districts have been created. These districts are aimed not at gentrification but neighborhood stability. At first, the push for bungalow preservation came from City Hall, but the effort soon caught fire in the community. There was a powerful undercurrent of nostalgia behind the districts because they have been "home" to so many Chicagoans. Not only did both Mayor Daleys in Chicago history live in bungalows, but so did First Lady Michelle Obama. Illinois's notorious former Governor Rod Blagojevich also resided in a bungalow, while he was in office and while he awaited criminal trial. More importantly, the bungalow was the home of choice for ethnic immigrants or African-American migrants making their first tentative steps into the middle class. The popularity of bungalow preservation is particularly strong among baby boomers who grew

8. Burnham, "Making History," 19.

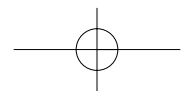


up in these homes. As David Lowenthal has noted, the baby boomers have been particularly industrious in transforming their nostalgia for a vanished youth into a preserved heritage. ${ }^{9}$ Yet, is bungalow preservation rooted in nostalgia, or a genuine sense of place?

As in Sheridan Park, concern over real estate values played an early and sustaining role in the creation of the various bungalow historic districts. Historian Daniel Bluestone helped shape the initial historical arguments for creating bungalow historic districts. The fact that bungalows constituted such a large percentage of the city's housing stock made their future a public policy concern. As these structures approached eighty to one hundred years in age, Chicago had to face the prospect of large-scale replacement, renovation, or steady deterioration. Encouraging renovation was not only an environmentally friendly choice, it was clearly in the best interests of the largely workingclass residents of the bungalow belt. The real estate market would not have supported large-scale replacement with new construction in most neighborhoods, and where it would have, it could not have been an affordable option for current owners. Unlike the case of Sheridan Park, the tax-certified renovations made possible by historic district status were a tool not of gentrification that ultimately displaced many residents; rather preservation programs were utilized to help keep current residents in their homes.

Another significant difference between Sheridan Park and the Historic Chicago Bungalow Initiative is the role that history and memory have played in the process. In the case of Sheridan Park, there has been virtually no continuing public history activity since the preparation of the National Register nomination. The "Heart of Uptown" was reinvented as Sheridan Park, but there was no continuing community concern with history. The National Register argument was an example of commercial memory. The action of real estate developers in the past was resurrected and designated as historically significant in order to foster commercial development in the future. ${ }^{10}$ After serving its commercial purpose the well-researched story was of no further interest to either developers or their new residents. Of course, reinvented Sheridan Park was an area of multiple-occupancy buildings populated by young and single residents, many of whom were not inclined to put down roots in the neighborhood. Nor was the argument put forward that the district represented the work of lesser architects whose collective effort was significant in shaping the look of the city, a storyline designed to inspire an interest in the past.

In contrast, bungalows were by and large occupied by their owners, many with children growing up and going to school in the community. These people naturally had a stronger interest in their neighborhood and its history. Not

9. David Lowenthal, The Past is a Foreign Country (New York: Cambridge University Press, 1985), 5-7.

10. For more on commercial memory see Robert Burgoyne, "From Contested to Consensual Memory: The Rock and Roll Museum and Hall of Fame," in Contested Pasts: The Politics of Memory, ed. Katherine Hodgkin and Susannah Redstone (New York: Routledge, 2003), 195-208.

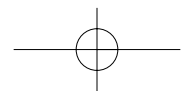


surprisingly, public history programming initiatives were greater in this setting. Some programs were the results of the City of Chicago's exercise of "official memory." One salutary result of this was the publication of an illustrated history, The Chicago Bungalow. The volume was written by leading Chicago historians and sponsored by the City of Chicago's Department of Community Development and the Chicago Architectural Foundation. ${ }^{11}$ There has also been a grassroots or vernacular response to bungalow belt preservation. An example of this was the creation of the West Ridge Bungalow Neighbors, a voluntary group of residents who work to help each other with preserving and beautifying their homes and educating their neighbors about the heritage of their historic district community. The group organizes workshops on woodwork restoration or flowerbox gardening, tours of other bungalow communities, visits to nearby historic sites, and the classic expression of community solidarity, pot-luck suppers.

The City of Chicago has largely privatized its involvement with the bungalow through the creation of the Historic Chicago Bungalow Association. This not-for-profit organization receives city funds to offer grants, loans, and technical advice designed to keep homeowners in their bungalows, and it also seeks out private sources of money to support its efforts. The goal of the association is "housing preservation," not history. Yet it recognizes that nurturing the sense of heritage that many bungalow owners feel enhances the prospect that bungalows will be valued as housing stock.

In the 1920s much of the "bungalow belt" in Chicago was home to European immigrants or the children of immigrants. The blocks of brick homes, the surrounding factories, and the adjacent churches together acted as a vehicle of Americanization. Today their children are grouped together as "white ethnics," but a century ago they were greatly divided by language, culture, and religion. One thing the heterogeneous population shared was pride in their homogeneous homes. The Historic Chicago Bungalow Association hopes to build in today's equally diverse historic district neighborhoods, with new immigrant families, a sense of the past that can be shared with neighbors both within the bungalow belt and across the city. One public history vehicle for doing this is the collection "Tales of the Bungalow Belt." These local history snapshots of the famous, the infamous, and the ordinary people who made bungalows home sustain the notion that these ubiquitous residences are a key element in Chicago's historical identity. Through a Web site dedicated to bungalow stories, residents are encouraged to speak, to present their history as relevant to the present and future. Many property owners in the bungalow districts feel a historical connection that rises above the academic architectural history argument behind Sheridan Park and taps into the genuine lived experience of urbanites. ${ }^{12}$

11. Dominic Pacyga (ed.), The Chicago Bungalow (Chicago: Arcadia, 2003).

12. For more information see, http://www.chicagobungalow.org/

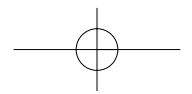


The thousands of historic districts that cover American cities are in equal parts zones of urban planning and sites of memory. Too often the type of history presented in historic districts is a function of commercial memory, a story constructed out of primary sources to justify a commercial vision. Most of such historic districts are not as hotly contested as Sheridan Park cum Uptown in Chicago, and commercial vision is absolutely vital to the continued existence of all communities. Districts created by commercial memory do play a role in preserving historic building stock, which is environmentally sound and may in the long run play a role in giving urban residents a sense of time. In the short run, however, history that is constructed without reference to the personal memory of the people who reside in the community lives only in the files of the State Office of Historic Preservation. Vernacular memory is constructed out of a shared sense of the past that grows out of a shared experience of the present. When preservation is able to tap into this common consensual memory of a community, it is unlikely that critics will look at the resulting historic district and ask, "where is the history?"

Theodore J. Karamanski is Professor of History and Director of the Public History Program at Loyola University Chicago. His public history work has focused on Great Lakes region cultural resource management, environmental history, and American Indian rights. His most recent book is, with Eileen M. McMahon, North Woods River: The St. Croix Valley in Upper Midwest History (Wisconsin, 2009). He is a past president of the National Council on Public History.

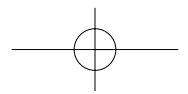

